\title{
THYROXINE-BINDING BY SERUM PROTEIN IN PREGNANCY AND IN THE NEWBORN
}

\author{
By JACOB ROBBINS AND JAMES H. NELSON
}

\author{
(From the National Institute of Arthritis and Metabolic Diseases, National Institutes of Health, \\ Department of Health, Education and Welfare, Public Health Service, Bethesda, Md., \\ and the Department of Obstetrics, District of Columbia General Hospital, \\ Washington, D. C.)
}

(Submitted for publication August 31, 1957; accepted September 26, 1957)

Thyroid structure and function in man undergo a number of changes during pregnancy. The thyroid gland may become enlarged and hyperplastic $(1,2)$, thyroidal uptake of radioiodine is increased $(3,4)$, "conversion" of blood iodide to organic form is more rapid (4), and the serum proteinbound iodine (PBI) is elevated $(5,6)$. Although these alterations are like those seen in hyperthyroidism, they appear to be associated, in early pregnancy at least, with an unequivocally euthyroid state. Whereas the PBI rises as early as the first or second month of gestation, and remains at about the same level throughout pregnancy, elevation of the basal metabolic rate $(2,7)$ begins in the latter half of pregnancy and rises progressively. Circulatory changes, such as increased cardiac output (8), may precede the rise in oxygen consumption but these also change progessively until shortly before term.

It has been postulated that alterations in the interaction of thyroid hormone with serum proteins might provide an explanation for these paradoxical findings (6). Inasmuch as circulating thyroxine is largely bound to what appears to be a specific alpha globulin (TBP) $(9,10)$, attention has been directed toward this protein in pregnancy. It has been demonstrated that TBP in pregnancy has an increased ability to complex thyroxine (10-13). In the present study, the thyroxine-binding capacity of TBP has been quantitated during the course of normal pregnancy and in newborn infants. From these data it has been possible to calculate an approximate concentration of free thyroxine in the serum of these subjects.

\section{METHODS}

Serum was obtained from 16 women during and after uncomplicated pregnancies, usually after an overnight fast, from umbilical vein blood sampled at delivery in three subjects, and from external jugular venipuncture in two infants on the third day after delivery. Mixtures of serum with $\mathrm{I}^{131}$-labeled L-thyroxine ${ }^{1}$ were prepared according to the procedure described previously (14). Prior to use, each of the eight thyroxine preparations employed was tested for radiochemical purity by chromatography, and was repurified, when necessary, to a purity of 90 per cent or better by an extraction procedure (15). Iodine analyses 2 were performed by a modification of the method of Zak, Willard, Myers, and Boyle (16). The thyroxine-serum mixtures were subjected to zone electrophoresis on filter paper strips, using barbital buffer, $\mathrm{pH} 8.6$, ionic strength 0.1 , and a "reverse-flow" technique (15). This modification of the electrophoresis procedure avoided the inclusion of albumin-bound thyroxine in the alpha globulin zone.

For measurement of the thyroxine-binding capacity of TBP, the quantity of thyroxine added to each serum was sufficient to effectively saturate the thyroxine-binding sites on TBP. Actual saturation of these sites is approached asymptotically (15). Analysis of data obtained with normal sera (10), however, had indicated that the amount of thyroxine associated with alpha globulin reaches an effective plateau when less than 60 per cent of the serum thyroxine is in the alpha globulin zone. In most instances, the mixtures were such that 20 per cent to 40 per cent of the thyroxine were in the alpha globulin zone. This was usually achieved by the addition of between 1 and $2 \mu \mathrm{g}$. of thyroxine per $\mathrm{ml}$. of serum. The average value for at least three serum mixtures, expressed as the quantity of thyroxine associated with TBP, was taken as the thyroxine-binding capacity of TBP. Barring any qualitative variation in the TBP sites for thyroxine, this value expressed in moles would be equivalent to the concentration of such sites.

Equations for the calculation of free or unbound thyroxine in serum have been described earlier (10). In the present calculations, the values employed for serum albumin concentration were $4.5 \mathrm{Gm}$. per cent in nonpregnant adults, and $3.4 \mathrm{Gm}$. per cent in pregnancy and in the newborn (17). The basis for the use of assumed rather than measured albumin values, and other assumptions involved in the calculations are considered in the discussion.

1 Obtained from Abbott Laboratories, Oak Ridge, Tennessee.

2 Performed by J. Benotti, Boston Medical Laboratories, Boston, Massachusetts. 


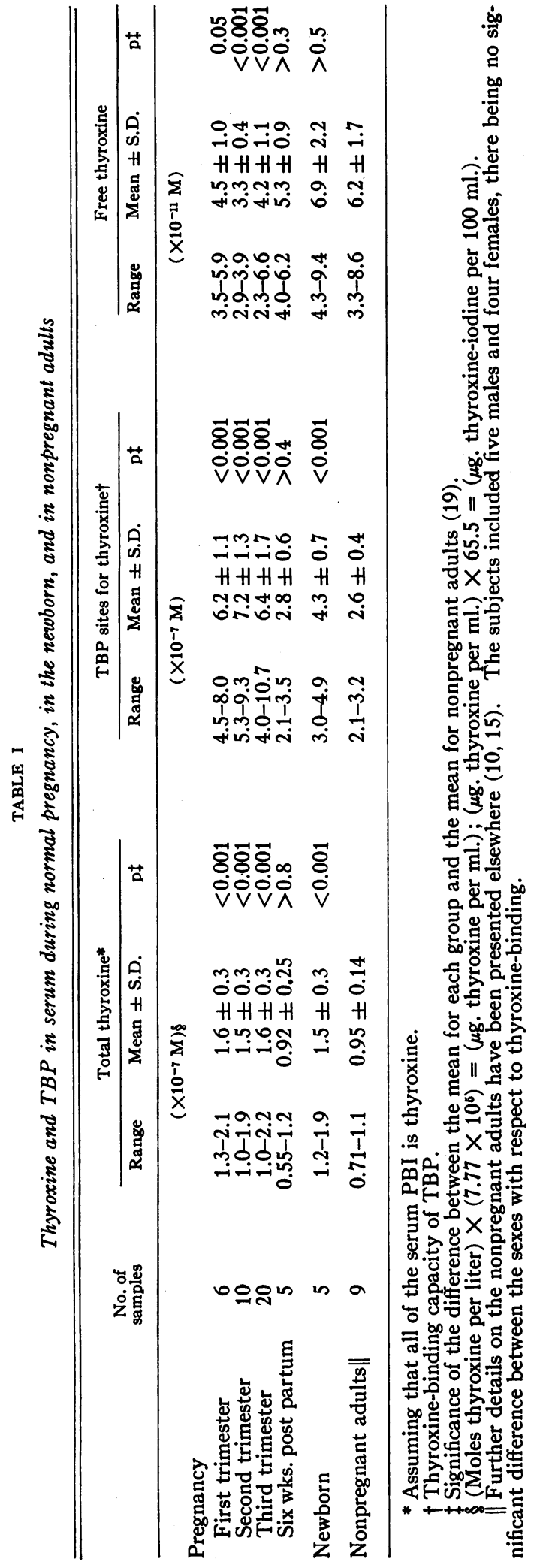

\section{RESULTS}

From a qualitative standpoint, no differences were detected between thyroxine-protein interactions in serum from normal adult, pregnant, and newborn subjects. At concentrations of the order of $0.2 \mu \mathrm{g}$. or less of added thyroxine per $\mathrm{ml}$. of serum, most of the serum radioiodine had an electrophoretic mobility, at $\mathrm{pH} 8.6$, intermediate between alpha-1 and alpha-2 globulin. The remainder was associated with albumin, with the exception of approximately 5 per cent or less which was sometimes found just ahead of albumin. This "prealbumin" zone was poorly separated from albumin, and its significance is not clear (18). The beta and gamma globulin zones did not contain significant amounts of thyroxine. When larger amounts of thyroxine were added to the serum, a point was reached at which the thyroxine associated with alpha globulin no longer increased. Excess thyroxine migrated with albumin.

Results of quantitative studies in normal pregnancy are summarized in Table $I$. Included are multiple samples from five subjects who were followed throughout pregnancy (cf., Table II), samples from two subjects studied only in the second month of gestation, and samples from nine subjects studied only at term. The results are expressed as molar concentrations in order to permit interchangeable use of the terms "thyroxinebinding capacity of TBP" and "concentration of TBP sites for thyroxine." Factors for conversion of moles to the more familiar $\mu \mathrm{g}$. of thyroxine and $\mu \mathrm{g}$. of protein-bound iodine are given in Table I.

Total serum thyroxine was elevated above the normal range early in pregnancy (the earliest time studied was in the sixth week of gestation) and persisted without significant change until term. By six weeks post partum, the level was back to normal. The thyroxine-binding capacity of TBP was likewise elevated at the earliest time examined. The increase in thyroxine-binding capacity, however, was relatively greater than the rise in total thyroxine. As a consequence, from 15 to 34 per cent (mean, 24 per cent) of the available sites on TBP were occupied in pregnancy in contrast to from 21 to 42 per cent (mean, 34 per cent) in nonpregnant adults. The mean thyroxine-binding capacity for the various trimesters did not differ significantly from each other $(p>0.1)$ and, in the 
TABLE II

Thyroxine and TBP in serum during normal pregnancy

\begin{tabular}{|c|c|c|c|c|c|c|c|c|c|c|c|c|c|c|c|}
\hline \multirow[b]{2}{*}{ Case no. } & \multicolumn{5}{|c|}{$\begin{array}{l}\text { Total thyroxine } \\
\left(\times 10^{-7} \mathrm{M}\right)\end{array}$} & \multicolumn{5}{|c|}{$\begin{array}{c}\text { TBP sites for thyroxine } \\
\left(\times 10^{-7} \mathrm{M}\right)\end{array}$} & \multicolumn{5}{|c|}{$\begin{array}{l}\text { Free thyroxine } \\
\left(\times 10^{-11} \mathbf{M}\right)\end{array}$} \\
\hline & 1 & 2 & 3 & 4 & 5 & 1 & 2 & 3 & 4 & 5 & 1 & 2 & 3 & 4 & 5 \\
\hline \multicolumn{16}{|l|}{$\begin{array}{l}\text { Months* } \\
\text { pregnant }\end{array}$} \\
\hline $\begin{array}{l}2 \\
3 \\
4 \\
5 \\
6 \\
7 \\
8 \\
9\end{array}$ & $\begin{array}{l}1.0 \\
1.4 \\
1.5 \\
1.8 \\
1.5\end{array}$ & $\begin{array}{l}1.3 \\
1.4 \\
1.4 \\
1.4 \\
1.8 \\
1.5\end{array}$ & $\begin{array}{l}1.4 \\
1.4 \\
1.5 \\
1.5 \\
1.8\end{array}$ & $\begin{array}{l}2.1 \\
\\
1.9 \\
2.2 \\
1.7\end{array}$ & 1.8 & $\begin{array}{l}5.3 \\
5.8 \\
6.7 \\
7.6 \\
9.3\end{array}$ & $\begin{array}{l}4.5 \\
6.1 \\
7.2 \\
7.0 \\
7.3 \\
6.7\end{array}$ & $\begin{array}{l}5.9 \\
7.5 \\
7.7 \\
6.6 \\
5.7\end{array}$ & $\begin{array}{r}6.2 \\
\\
8.9 \\
7.0 \\
10.7\end{array}$ & 8.0 & $\begin{array}{l}2.9 \\
3.9 \\
3.6 \\
3.8 \\
2.4\end{array}$ & $\begin{array}{l}4.7 \\
3.7 \\
3.0 \\
3.1 \\
3.9 \\
3.6\end{array}$ & $\begin{array}{l}3.8 \\
2.9 \\
3.0 \\
3.7 \\
5.3\end{array}$ & $\begin{array}{l}5.9 \\
\\
3.4 \\
5.5 \\
2.3\end{array}$ & 3.5 \\
\hline Term & & 1.7 & 2.2 & & 1.9 & & 7.7 & 6.0 & & 7.6 & & 3.3 & 6.6 & & 4.1 \\
\hline \multicolumn{16}{|l|}{$\begin{array}{l}\text { Days post } \\
\text { partum }\end{array}$} \\
\hline $\begin{array}{r}3 \\
10 \\
24 \\
31 \\
38\end{array}$ & 1.1 & $\begin{array}{l}1.7 \\
1.5\end{array}$ & 1.5 & $\begin{array}{l}1.8 \\
1.5 \\
1.2\end{array}$ & 1.4 & 3.9 & $\begin{array}{l}7.6 \\
6.3\end{array}$ & 4.8 & $\begin{array}{l}7.7 \\
6.6 \\
4.5\end{array}$ & 8.4 & 4.7 & $\begin{array}{l}3.4 \\
3.9\end{array}$ & 5.5 & $\begin{array}{l}3.7 \\
3.7 \\
4.3\end{array}$ & 2.5 \\
\hline
\end{tabular}

* Lunar.

subjects studied serially (Table II), no consistent trend during pregnancy was observed.

The calculated free thyroxine, on the other hand, did not increase. Indeed, the mean value for each pregnancy group was significantly lower than in the nonpregnant subjects. The majority of the individual values in pregnancy, however, fell within the range found for nonpregnant subjects. When the trimesters of pregnancy were compared, the mean free thyroxine for the first and third trimesters were not significantly different $(p>$ 0.5 ), whereas the mean for the second trimester was significantly lower $(p<0.01, p<0.02)$. In the subjects in Table II, however, no consistent trend during pregnancy was observed, suggesting that this difference may be in error due to the small samples.

Both free thyroxine and the thyroxine-binding capacity returned to normal by the sixth week post partum, together with the PBI.

The findings in the newborn are presented in Table III and summarized in Table I. Total thyroxine was significantly higher than in nonpregnant adults, and was equal to or lower than in the mother. The thyroxine-binding capacity of TBP, although significantly higher than in nonpregnant

TABLE III

Thyroxine and TBP in serum of newborn

\begin{tabular}{|c|c|c|c|c|c|c|c|c|c|c|c|c|c|c|c|}
\hline \multirow[b]{2}{*}{ Case no. } & \multicolumn{5}{|c|}{$\begin{array}{c}\text { Total thyroxine } \\
\left(\times 10^{-7} \mathrm{M}\right)\end{array}$} & \multicolumn{5}{|c|}{$\begin{array}{l}\text { TBP sites for thyroxine } \\
\left(\times 10^{-7} \mathrm{M}\right)\end{array}$} & \multicolumn{5}{|c|}{$\begin{array}{l}\text { Free thyroxine } \\
\left(\times 10^{-11} \mathbf{M}\right)\end{array}$} \\
\hline & 1 & 2 & 3 & 4 & 5 & 1 & 2 & 3 & 4 & 5 & 1 & 2 & 3 & 4 & 5 \\
\hline $\begin{array}{l}\text { Mother* } \\
\text { Fetus } \dagger\end{array}$ & 1.5 & $\begin{array}{l}1.7 \\
1.2\end{array}$ & $\begin{array}{l}2.2 \\
1.4\end{array}$ & 1.8 & $\begin{array}{l}1.9 \\
1.9 \S \\
1.3\end{array}$ & 7.0 & $\begin{array}{l}7.7 \\
4.5\end{array}$ & $\begin{array}{l}6.0 \\
4.5\end{array}$ & 7.7 & $\begin{array}{l}7.6 \\
4.4\end{array}$ & 3.4 & $\begin{array}{l}3.3 \\
4.3\end{array}$ & $\begin{array}{l}6.6 \\
5.3\end{array}$ & 3.7 & $\begin{array}{l}4.1 \\
8.7 \S \\
7.2\end{array}$ \\
\hline Infant $\ddagger$ & 1.4 & & & 1.8 & & 3.0 & & & 4.9 & & 9.4 & & & 6.7 & \\
\hline
\end{tabular}

* Mother's serum obtained at same time as fetus or infant.

$\dagger$ Umbilical vein at term.

$\$$ Three days post partum.

$\$$ The PBI in this serum was not measurable ( $<$ blank), possibly due to contamination with mercury. The infant appeared to be normal. Two values for total thyroxine were assumed-one equal to that in the mother, the other differing from the mother to the extent found in Case No. 3. The former value was used in Table I. 
adults, was consistently lower than in the mother. Free thyroxine was, in all but one case, higher than in the mother, but not significantly different from the nonpregnant adult value.

\section{DISCUSSION}

It is clear from the present study, and from earlier evidence (10-13), that uncomplicated pregnancy in man is accompanied by an increase in thyroxine-binding by at least one component of the serum alpha globulins. This thyroxine-binding alpha globulin in pregnancy has the characteristic electrophoretic mobility of TBP in normal human serum both at $\mathrm{pH} 8.6$ and at $\mathrm{pH} 4.5$ (13). As in normal serum, there is no direct evidence that TBP is a single protein; nevertheless, this seems likely in view of the highly specific nature of its interaction with thyroxine $(20,21)$ and its very low concentration in serum (10). In the foregoing treatment of the data, and in this discussion, the assumption is made that TBP is a single protein species.

The increase in thyroxine-binding capacity of TBP, as measured in this study, could result either from an increase in the number or availability of binding sites per molecule of TBP, or from an increase in the concentration of TBP. The latter possibility appears more reasonable, although no evidence bears directly on this question. Other serum proteins undergo changes in concentration during pregnancy, and the alpha globulins, as a group, increase $(22,23)$. It is possible that TBP participates in these changes and that the alterations in thyroid physiology during pregnancy are a fortuitous result of this initial event. Since it has been shown that administration of estrogen to nonpregnant individuals results in an increase of PBI $(24)$ and TBP $(25,26)$ in serum, it appears that the increase in estrogen which occurs during pregnancy (27) may initiate these changes in the pregnant subject.

The mechanism by which a change in the concentration of TBP might affect thyroid physiology is, likewise, a matter for speculation. Circumstantial evidence presented earlier $(10,28)$ has suggested a correlation between the level of free thyroxine in serum, as calculated by the methods described, and the physiological state of the individual with respect to hyper-, hypo-, or euthyroidism. Since an increase in TBP without a con- comitant change in thyroxine would result in a low free thyroxine level, homeostatic mechanisms may operate in such a situation to restore the normal free thyroxine level. This could be achieved by an increase in hormone secretion by the thyroid gland, by a decrease in thyroxine degradation, or by a combination of these processes. Evidence quoted in the introduction indicates that thyroid gland function does, in fact, increase. Thyroxine degradation in human pregnancy has not been defined, but it has been suggested (10) that, at least in some situations, the amount of thyroxine degraded may be proportional to the free thyroxine level in serum. In the study by Danowski, Schwartz, Rhodes, Yoder, Puntereri, and Mateer (29), although no difference was observed between pregnant and nonpregnant subjects, the use of nonphysiological amounts of thyroxine makes interpretation difficult.

It is probably significant, however, that, despite evidence that thyroid gland hyperfunction persists throughout pregnancy (4), the levels of $\mathrm{PBI}, \mathrm{TBP}$ and free thyroxine remain constant after the initial rise in the first trimester. This suggests that factors other than those discussed above may be operative; for example, a progressive increase in thyroxine degradation in pregnancy could explain this discrepancy. Such an increase might also be responsible for the failure of the mean free thyroxine level in pregnancy to equal that in nonpregnant adults. The slightly lower levels in pregnancy, however, appear sufficient to maintain a state of euthyroidism.

Several other observations are consistent with the postulated interrelationship between the concentration of TBP sites for thyroxine and the level of free thyroxine, and with the effect of the latter on the physiological state of the subject. The amelioration of hyperthyroidism which sometimes occurs during pregnancy (e.g., 30) could result from an increase in TBP sites in the presence of unaltered thyroid hormone secretion. In hyperthyroidism per se, the concentration of TBP sites remains normal (10), but in pregnancy complicated by hyperthyroidism, the expected increase in TBP sites takes place (26). Estrogen treated subjects are able to tolerate PBI levels higher than normal without development of hyperthyroid signs $(24,25)$; and, in athyreotic subjects on constant thyroid hormone replacement therapy, es- 
trogen administration may induce signs of hypothyroidism (25).

The observation has been made that $\mathrm{I}^{131}$-labeled triiodothyronine passes less readily from pregnancy serum into red cells in vitro than from normal serum (31). This finding is also consistent with a low free thyroxine concentration and a relatively high concentration of unoccupied TBP sites, since triiodothyronine interacts with these TBP sites (10).

It is important to reemphasize (10), at this point, that a number of assumptions are involved in the calculation of free thyroxine as employed in this study. Included among these are the assumptions: $a$ ) that albumin and TBP each have a single type of binding site for thyroxine at the thyroxine levels employed, $b$ ) that there are no interactions between successively bound thyroxine molecules, and $c$ ) that zone electrophoresis provides satisfactory estimates of the maximum number of sites on TBP and of the ratio between the intrinsic association constants for the thyroxinealbumin and thyroxine-TBP complexes. These assumptions, as discussed elsewhere $(10,15)$, appear to be valid.

Other assumptions are: $d$ ) that the thyroxineprotein interaction in vitro (i.e., in barbital buffer at $\mathrm{pH} 8.6$ under equilibrium conditions) is the same as under physiological conditions in vivo, $e$ ) that human and bovine albumin do not differ in their interaction with thyroxine, and $f$ ) that the thyroxine-albumin interaction is the same in normal and abnormal states. These assumptions obviously require evaluation and clearly limit any reliance on the calculated free thyroxine values in an absolute sense. The most questionable assumptions ( $d$ and $e$.), however, would not affect the calculation when used as a basis for comparison between groups of subjects.

A further consideration with respect to the calculations in pregnancy is the possibility that the increment in serum PBI may not be thyroxine. The solubility of this PBI in butanol (6) is consistent with it being thyroxine, but is inconclusive. One chromatographic study of postpartum serum (4), however, could demonstrate only thyroxine and triiodothyronine.

As indicated in the Methods section, precise knowledge of the concentration of albumin is not critical to the calculations in the present study.
For example, in a normal serum with $10^{-7} \mathrm{M}$ thyroxine and 2.7 times $10^{-7} \mathrm{M}$ TBP sites for thyroxine, a 50 per cent change in albumin concentration from the value employed results in approximately a 10 per cent change in free thyroxine in the opposite direction. ${ }^{3}$ In a pregnancy serum with 1.4 times $10^{-7} \mathrm{M}$ thyroxine and 5.1 times $10^{-7} \mathrm{M}$ TBP sites, a 50 per cent change in albumin results in a 2 per cent change in free thyroxine. For this reason, albumin was not measured in the individual sera, and the gradual fall in serum albumin which occurs during pregnancy was disregarded. This simplification, of course, could not be applied to all situations. In nephrosis, for example, when the concentration of both albumin and TBP may be very low (10), the albumin level becomes of considerable importance in determining the concentration of free thyroxine.

The findings in the newborn subjects are of interest with regard to the question of the dependence of the fetus on maternal thyroid function. The existence of an independent fetal thyroid function in the human is supported by the ability of hypothyroid women to give birth to apparently normal infants (32) and, conversely, by the finding of retarded bone age in newborn athyreotic infants of normal mothers (33). The slow passage of maternal thyroxine into the fetus (34) indicates that TBP does not readily pass the placental barrier, if at all, and that the placenta probably does not transfer free thyroxine by any mechanism other than diffusion. It appears, therefore, that the higher concentration of free thyroxine in the fetal circulation must be maintained by the fetal thyroid gland. The demonstration of a difference between the concentration of TBP in maternal and fetal blood, which corroborates the findings of Dowling, Freinkel, and Ingbar (13), is not surprising in view of differences in the concentration of other serum proteins $(22,35)$, and it is of interest that the alpha-1 and alpha-2 globulin components are lower in fetal blood.

The two infants studied on the third day after birth did not appear to have PBI levels higher than that in placental blood, as has been described in infants of this approximate age $(36,37)$. Measurement of TBP in a larger group of in-

${ }^{3}$ The change in free thyroxine is greater when albumin decreases than when albumin rises (11 per cent and 9 per cent, respectively). 
fants and young children will be required to determine whether TBP changes may persist independent of the influence of the high maternal estrogen level.

Since pregnancy and estrogen administration produce increases in PBI and TBP in the serum, it appears possible that similar alterations might occur in women during the menstrual cycle. Attempts to detect such changes in the PBI revealed no unequivocal cyclic variation $(5,38)$. In the nonpregnant subjects who served as controls for the present study, no significant differences between TBP in men and women were observed (15), but the time of sampling was not correlated with the menstrual cycle. Recent studies on the baboon, however, have revealed a rise in PBI during the postovulatory phase (39). It will be of interest to determine whether this PBI change accompanies a cyclic variation in TBP.

The literature quoted in this discussion, it should be pointed out, has been limited to studies in man, except for that referred to just above. Although considerable data has been recorded on thyroid interrelationships in pregnant animals, differences in placentation and in thyroxine-protein interactions (40) among the species make it hazardous to apply these findings to human pregnancy.

\section{SUM MARY}

The thyroxine-binding capacity of the thyroxine-binding alpha globulin of serum (TBP) has been measured during pregnancy in normal women. This capacity, which probably reflects the concentration of TBP, rises in the early weeks of pregnancy to a level which is approximately two and one-half times that in normal adults, remains essentially unchanged throughout pregnancy, and returns to normal within six weeks post partum. As a result of this rise in TBP, the concentration of free thyroxine in serum, calculated with the aid of certain assumptions, is significantly lower than that in nonpregnant adults, despite a rise in serum PBI.

The thyroxine-binding capacity of TBP in the newborn is approximately one and one-half times that in normal adults, and is lower than that in the mother. Since the PBI in the newborn is approximately equal to that in the mother, the concentration of free thyroxine is significantly higher.
This level, however, is the same as that in nonpregnant adults.

\section{ACKNOWLEDGMENT}

The authors wish to thank Miss Dorothea Jermany for technical assistance.

\section{REFERENCES}

1. Mussey, R. D. The thyroid gland and pregnancy. Amer. J. Obstet. Gyn. 1938, 36, 529.

2. Freedberg, I. M., Hamolsky, M. W., and Freedberg, A. S. The thyroid gland in pregnancy. New Engl. J. Med. 1957, 256, 505.

3. Pochin, E. E. The iodine uptake of the human thyroid throughout the menstrual cycle and in pregnancy. Clin. Sci. 1952, 11, 441.

4. Ferraris, G. M., and Scorta, A. Comportamento di alcuni tests di funzione tiroidea in gravidanza $e$ in puerperio. Minerva ginec. 1955, 7, 308.

5. Heinemann, M., Johnson, C. E., and Man, E. B. Serum precipitable iodine concentrations during pregnancy. J. clin. Invest. 1948, 27, 91.

6. Danowski, T. S., Gow, R. C., Mateer, F. M., Everhart, W. C., Johnston, S. Y., and Greenman, J. H. Increases in serum thyroxine during uncomplicated pregnancy. Proc. Soc. exp. Biol. (N. Y.) 1950, 74, 323.

7. Sandiford, I., and Wheeler, T. The basal metabolism before, during, and after pregnancy. J. biol. Chem. 1924, 62, 329.

8. Burwell, C. S. Circulatory adjustments to pregnancy. Johns Hopk. Hosp. Bull. 1954, 95, 115.

9. Gordon, A. H., Gross, J., O'Connor, D., and PittRivers, R. Nature of the circulating thyroid hormone-plasma protein complex. Nature (Lond.) 1952, 169, 19.

10. Robbins, J., and Rall, J. E. The interaction of thyroid hormones and proteins in biological fluids in Recent Progr. Hormone Res. New York, Academic Press Inc. 1957, vol. 13, p. 161.

11. Robbins, J. Thyroxine-binding capacity of serum in pregnancy. Fed. Proc. 1956, 15, 153.

12. Dowling, J. T., Freinkel, N., and Ingbar, S. H. Thyroxine-binding by sera of pregnant women. J. clin. Endocrin. 1956, 16, 280.

13. Dowling, J. T., Freinkel, N., and Ingbar, S. H. Thyroxine-binding by sera of pregnant women, new-born infants, and women with spontaneous abortion. J. clin. Invest. 1956, 35, 1263.

14. Robbins,. J., and Rall, J. E. Thyroxine-binding capacity of serum in normal man. J. clin. Invest. 1955, 34, 1324.

15. Robbins, J. Reverse-flow zone electrophoresis. A method for determining the thyroxine-binding capacity of serum protein. Arch. Biochem. Biophys. 1956, 63, 461. 
16. Zak, B., Willard, H. H., Myers, G. B., and Boyle, A. J. Chloric acid method for determination of protein-bound iodine. Analyt. Chem. 1952, 24, 1345.

17. Mack, H. C. The Plasma Proteins in Pregnancy. Springfield, Charles C Thomas, 1955.

18. Robbins, J., Rall, J. E., and Petermann, M. L. Thyroxine-binding by serum and urine proteins in nephrosis. Qualitative aspects. J. clin. Invest. 1957, 36, 1333.

19. Snedecor, G. W. Statistical Methods, 4th ed. Ames, The Iowa State College Press, 1947.

20. Robbins, J., and Rall, J. E. Effects of triiodothyronine and other thyroxine analogues on thyroxinebinding in human serum. J. clin. Invest. 1955, 34, 1331.

21. Larson, F. C., and Albright, E. C. The specificity of thyroxine binding by serum alpha globulin. Endocrinology 1955, 56, 737.

22. Longsworth, L. G., Curtis, R. M., and Pembroke, R. H., Jr. The electrophoretic analysis of maternal and fetal plasmas and sera. J. clin. Invest. 1945, 24, 46.

23. Coryell, M. N., Beach, E. F., Robinson, A. R., Macy, I. G., and Mack, H. C. Metabolism of women during the reproductive cycle. XVII. Changes in electrophoretic patterns of plasma proteins throughout the cycle and following delivery. J. clin. Invest. $1950,29,1559$.

24. Engstrom, W. W., and Markardt, B. Influence of estrogen on thyroid function. J. clin. Endocrin. 1954, 14, 215.

25. Dowling, J. T., Freinkel, N., and Ingbar, S. H. Effect of diethylstilbestrol on the binding of thyroxine in serum. J. clin. Endocrin. 1956, 16, 1491.

26. Robbins, J. Unpublished data.

27. Smith, G. VanS., and Smith, O. W. Internal secretions and toxemia of late pregnancy. Physiol. Rev. 1948, 28, 1.

28. Robbins, J., and Rall, J. E. Physiological implications of thyroxine-binding by serum proteins (abstract). J. clin. Invest. 1957, 36, 923.
29. Danowski, T. S., Schwartz, R., Rhodes, G. J., Yoder, R. D., Puntereri, A. J., and Mateer, F. M. Serum protein-bound iodine levels following administration of thyroxine in various diseases. J. clin. Endocrin. 1955, 15, 1116

30. Astwood, E. B. The use of antithyroid drugs during pregnancy. J. clin. Endocrin. 1951, 11, 1045.

31. Hamolsky, M. W., Stein, M., and Freedberg, A. S. The thyroid hormone-plasma protein complex in man. II. A new in vitro method for study of "uptake" of labelled hormonal components by human erythrocytes. J. clin. Endocrin. 1957, 17, 33.

32. Parkin, G., and Greene, J. A. Pregnancy occurring in cretinism, and in juvenile and adult myxedema. J. clin. Endocrin. 1943, 3, 466.

33. Dorff, G. B. Sporadic cretinism in one of twins. Amer. J. Dis. Child. 1934, 48, 1316.

34. Grumbach, M. M., and Werner, S. C. Transfer of thyroid hormones across the human placenta at term. J. clin. Endocrin. 1956, 16, 1392.

35. Moore, D. H., Du Pan, R. M., and Buxton, C. L. An electrophoretic study of maternal, fetal, and infant sera. Amer. J. Obstet. Gynec. 1949, 57, 312.

36. Danowski, T. S., Johnston, S. Y., Price, W. C., McKelvey, M., Stevenson, S. S., and McCluskey, E. R. Protein-bound iodine in infants from birth to one year of age. Pediatrics 1951, 7, 240.

37. Man, E. B., Pickering, D. E., Walker, J., and Cooke, R. E. Butanol-extractable iodine in the serum of infants. Pediatrics 1952, 9, 32.

38. Danowski, T. S., Hedenburg, S., and Greenman, J. H. The constancy of the serum precipitable or protein-bound iodine in healthy adults. J. clin. Endocrin. 1949, 9, 768.

39. Van Zyl, A. Serum protein-bound iodine and serum lipid changes in the baboon (Papio ursinus). I. During the menstrual cycle. J. Endocrin. 1957, $14,309$.

40. Robbins, J., Apter, R. A., and Rall, J. E. Thyroxineprotein interactions in the serum of various animal species. Program of the Endocrine Society, Thirty-ninth Meeting, 1957, p. 50. 